\title{
Effect of aromatic pendants in maleic anhydride-co- octadecene polymer on the precipitation of asphaltenes extracted from heavy crude oil
}

\author{
Ruzhen Cheng ${ }^{1,2}$, Run Zou ${ }^{3}$, Long $\mathrm{He}^{4,5}$, Lei Liu, ${ }^{4,5}$, Chang $\mathrm{CaO}^{4,5}$, Xinyuan $\mathrm{Li}^{6}$, Xuhong \\ $\mathrm{Guo}^{1,2 *}, \operatorname{Jun} \mathrm{Xu}{ }^{1,2 *}$,
}

${ }^{1}$ School of Chemical Engineering, East China University of Science and Technology, Shanghai 200237, China

${ }^{2}$ Large Industrial Reactor Engineering Research Center of Ministry of Education, East China University of Science and Technology, Shanghai, 200237, China

${ }^{3}$ University of Manchester Institute of Science and Technology Department of Biomolecular Science, Manchester, UK M13 9PL

${ }^{4}$ SINOPEC Northwest Company of China Petroleum and Chemical Corporation, 466 Changchun South Road, Urumqi 834001, China

${ }^{5}$ Key Laboratory of Enhanced Oil Recovery in Carbonate Fractured-vuggy Reservoirs, CNPC, 466 Changchun South Road, Urumqi 834001, China

${ }^{6}$ Sino Oil King Shine Chemical Co., Ltd., Hebei Langfang 065000, China;

*To whom correspondence should be addressed. E-mail: xujun@ecust.edu.cn (Jun Xu) and guoxuhong@ecust.edu.cn (Xuhong Guo) 
The further extraction steps of asphaltene A from scraped pipeline deposit (Figure S1), the density and elemental composition of heavy crude oil (Table S1), and the detailed deduction process of asphaltene structure models (Table S2). 


\section{The extraction process of asphaltene $A$}

The further extraction steps of asphaltene A are as following: "First, the scraped pipeline deposit was dried in a vacuum oven at $80{ }^{\circ} \mathrm{C}$ overnight to remove water. Second, adding $1 \mathrm{~g}$ of the asphaltenes obtained in the previous step to $50 \mathrm{~mL}$ of toluene to fully dissolve it, the impurities such as metal oxides and silt were removed by suction filtration, and the toluene was removed by rotary evaporation. Finally, $1 \mathrm{~g}$ of the asphaltenes obtained in the previous step was added to $50 \mathrm{~mL}$ of $\mathrm{n}$-heptane, stirred at $50^{\circ} \mathrm{C}$ for 1 hour to remove light components, filtered to obtain pure powdered asphaltene, and dried in a vacuum oven to remove the solvent". The scraped pipeline deposit (left) and extracted asphaltenes (right) are shown in the Figure S1.

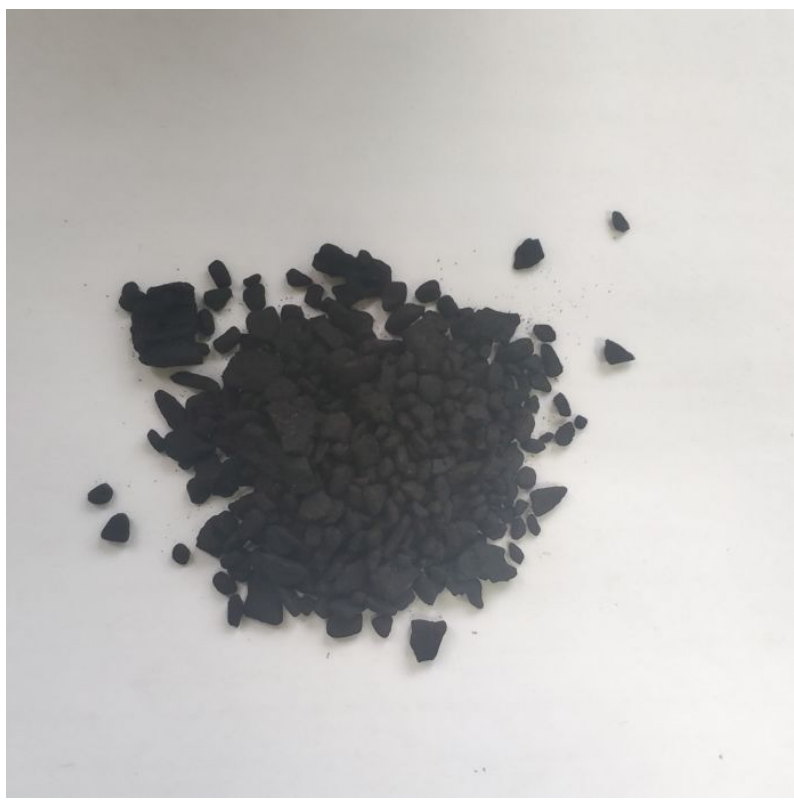




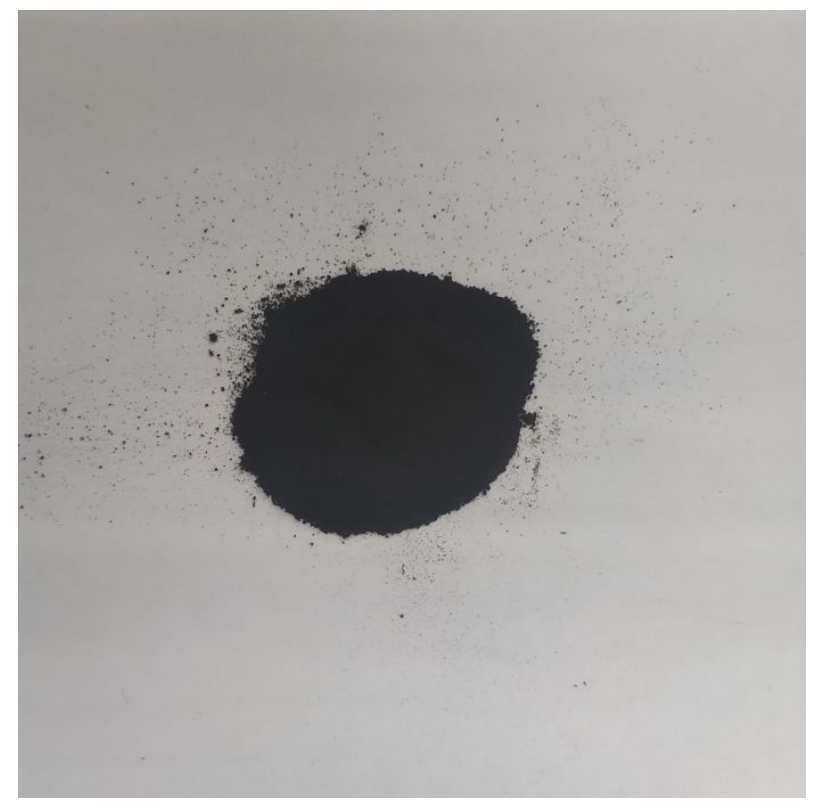

Figure S1. The scraped pipeline deposit (left) and extracted asphaltenes (right)

The density of heavy crude oil is $0.9833 \mathrm{~g} / \mathrm{cm}^{3}$, and the elemental composition is shown in Table S1.

Table S1. Elemental composition of the heavy crude oil

\begin{tabular}{ccccccc}
\hline & $\mathrm{C}$ & $\mathrm{H}$ & $\mathrm{O}$ & $\mathrm{N}$ & $\mathrm{S}$ & $N_{H} / N_{C}$ \\
\hline Content (\%) & 83.51 & 7.13 & 6.40 & 0.48 & 2.48 & 1.02 \\
\hline
\end{tabular}

\section{The detailed deduction process of molecular structures of both asphaltenes}

The improved Brown-Ladner (B-L) method was employed to calculate the structural parameters of asphaltenes, and the following is specific calculation results. 
The calculation of structural parameters of asphaltene A is taken as an example.

$\mathrm{H}_{\mathrm{S}}=\mathrm{H}_{\alpha}+\mathrm{H}_{\beta}+\mathrm{H}_{\gamma}=0.136+0.565+0.203=0.904$

$\mathrm{N}_{\mathrm{H}} / \mathrm{N}_{\mathrm{C}}=6.687 \times 12 / 79.61=1.008$

The number of $\mathrm{C}, \mathrm{H}, \mathrm{N}, \mathrm{O}$ and $\mathrm{S}$ in the average molecules: $\mathrm{C}_{\mathrm{T}}=0.7961 \times 861 / 12=57$

$\mathrm{H}_{\mathrm{T}}=0.06687 \times 861=57.5 \quad \mathrm{~N}_{\mathrm{T}}=0.0122 \times 861 / 14=0.75$

$\mathrm{S}_{\mathrm{T}}=0.0416 \times 861 / 32=1 \quad \mathrm{O}_{\mathrm{T}}=0.08467 \times 861 / 16=4.5$

Mean molecular formula: $\mathrm{C}_{57} \mathrm{H}_{57.5} \mathrm{~N}_{0.75} \mathrm{~S}_{1} \mathrm{O}_{4.5}$

Number of various types of hydrogen: $\mathrm{H}_{\alpha}=0.136 \times \mathrm{H}_{\mathrm{T}}=0.136 \times 57.5=8$

$$
\begin{gathered}
\mathrm{H}_{\beta}=0.565 \times \mathrm{H}_{\mathrm{T}}=0.565 \times 57.5=32.5 \\
\mathrm{H}_{\gamma}=0.203 \times \mathrm{H}_{\mathrm{T}}=0.203 \times 57.5=11.5 \\
\mathrm{H}_{\mathrm{A}}=0.0965 \times \mathrm{H}_{\mathrm{T}}=0.0965 \times 57.5=5.5
\end{gathered}
$$

$\mathrm{H}_{\mathrm{S}}=\mathrm{H}_{\alpha}+\mathrm{H}_{\beta}+\mathrm{H}_{\gamma}=8+32.5+11.5=52$

$\mathrm{C}_{\mathrm{T}} / \mathrm{H}_{\mathrm{T}}=0.9921$

$f_{\mathrm{A}}=\frac{\mathrm{Ct} / \mathrm{Ht}-(\mathrm{H} \alpha+\mathrm{H} \beta+\mathrm{H} \gamma) / 2 \mathrm{Ht}}{\mathrm{Ct} / \mathrm{Ht}}=0.54$

$$
\mathrm{C}_{\mathrm{A}}=\mathrm{C}_{\mathrm{T}} \times f_{\mathrm{A}}=31
$$

$\mathrm{H}_{\mathrm{AU}} / \mathrm{C}_{\mathrm{A}}=\frac{\mathrm{HA}+\mathrm{H} \alpha / 2}{\mathrm{Ct} \times \mathrm{fA}}=0.30$

$\sigma=\frac{\mathrm{H} \alpha / 2}{\mathrm{HA}+\mathrm{H} \alpha / 2}=0.42$

$\mathrm{C}_{\mathrm{S}}=\mathrm{C}_{\mathrm{T}}-\mathrm{C}_{\mathrm{A}}=57-31=26$

$\mathrm{C}_{\alpha}=\mathrm{H}_{\alpha} / 2=4$

$\mathrm{C}_{\mathrm{I}}=\mathrm{C}_{\mathrm{A}^{-}}-\mathrm{C}_{\mathrm{AP}}=\mathrm{C}_{\mathrm{A}^{-}}\left(\mathrm{H}_{\mathrm{A}}+\mathrm{H}_{\alpha} / 2\right)=21$

$\mathrm{C}_{\mathrm{F}}=6+\mathrm{C}_{\mathrm{A}}-2 \mathrm{C}_{\mathrm{AP}}=18$

$\mathrm{R}_{\mathrm{A}}=\left(\mathrm{C}_{\mathrm{A}}-4\right) / 3=9$

$\mathrm{R}_{\mathrm{T}}=\mathrm{C}_{\mathrm{T}}+1-\mathrm{H}_{\mathrm{T}} / 2-\mathrm{C}_{\mathrm{A}} / 2=14$

$\mathrm{R}_{\mathrm{N}}=\mathrm{R}_{\mathrm{T}}-\mathrm{R}_{\mathrm{A}}=5$

$\mathrm{C}_{\mathrm{N}}=3 \mathrm{R}_{\mathrm{N}}=14$

$\mathrm{C}_{\mathrm{P}}=\mathrm{C}_{\mathrm{S}}-\mathrm{C}_{\mathrm{N}}=12$

$f_{\mathrm{N}}=\mathrm{C}_{\mathrm{N}} / \mathrm{C}_{\mathrm{T}}=0.25$

$f_{\mathrm{P}}=\mathrm{C}_{\mathrm{P}} / \mathrm{C}_{\mathrm{T}}=0.2$

$\mathrm{nCH}_{2} / \mathrm{nCH}_{3}=2.93 \mathrm{~A}_{1460} / \mathrm{A}_{1380}-3.7=1.24$

$\mathrm{N}_{\mathrm{CH} 3}=\mathrm{C}_{\mathrm{S}} /\left(2+\mathrm{nCH}_{2} / \mathrm{nCH}_{3}\right)=8$ 
$\mathrm{L}=\mathrm{C}_{\mathrm{P}} / \mathrm{N}_{\mathrm{CH} 3}=1.5$

$$
\mathrm{N}_{\mathrm{CH} 2}=1.18 \times \mathrm{N}_{\mathrm{CH} 3}=9
$$

Explanation of all symbols in the calculation process:

$\mathrm{H} / \mathrm{C}$ _ atomic ratio of hydrogen to carbon;

$\mathrm{Mn} \_$relative mean molecular weight;

$\mathrm{C} \%$ - percentage of carbon in asphaltenes;

$\mathrm{H} \%$ _ percentage of hydrogen in asphaltenes;

$\mathrm{S} \%$ _ percentage of sulfur in asphaltenes;

$\mathrm{N} \%$ _ percentage of nitrogen in asphaltenes;

$\mathrm{O} \%$ - percentage of oxygen in asphaltenes;

$\mathrm{H}_{\mathrm{A}}$ the number of hydrogen atoms connected to aromatic carbon;

$\mathrm{H} \alpha \_$the number of hydrogen atoms connected to the $\alpha-\mathrm{C}$ of the aromatic ring;

$\mathrm{H}_{\beta}$ - the number of hydrogen atoms on the $\beta$ - $\mathrm{C}$ of the aromatic ring and the remote $\mathrm{CH}_{2}$ and $\mathrm{CH}$ groups;

$\mathrm{H}_{\gamma}$ the number of hydrogen atoms in the $\gamma$ - $\mathrm{C}$ of the aromatic ring and the remote $\mathrm{CH}_{3}$;

$\mathrm{C}_{\mathrm{T}}$ - the total number of carbons in the molecule;

$\mathrm{H}_{\mathrm{T}}-$ the total number of hydrogens in the molecule;

$\mathrm{C}_{\mathrm{A}} \longrightarrow$ the number of aromatic carbons in the molecule;

$\mathrm{C}_{\mathrm{N}}$ - the number of naphthenic carbons in the molecule;

$\mathrm{C}_{\mathrm{P}}$ - the number of alkyl carbons in the molecule;

$\mathrm{C}_{\mathrm{S}}$ - the number of alkyl and cycloalkane carbons in the molecule;

$\mathrm{R}_{\mathrm{A}}$ the number of aromatic rings in the molecule; 
$\mathrm{R}_{\mathrm{N}}$ the number of naphthenic rings in the molecule;

$\mathrm{R}_{\mathrm{T}}$ - the number of rings in the molecule;

$f_{\mathrm{A}}$ the percentage of the aromatic carbons to the total carbons, referred to as the aromatic carbon ratio, also known as the degree of aromaticity;

$f_{\mathrm{N}}$ - the percentage of the naphthenic carbons to the total carbons;

$f_{\mathrm{P}}$ - the percentage of the alkyl carbons to the total carbons;

$\sigma-$ substitution rate of peripheral hydrogens on aromatic rings;

$\mathrm{H}_{\mathrm{AU}} / \mathrm{C}_{\mathrm{A}}-$ the condensation degree of aromatic rings;

$\mathrm{nCH}_{2} / \mathrm{nCH}_{3}$ — the ratio of methylene groups to methyl groups in the molecule;

$\mathrm{nCH}_{3} \longrightarrow$ the number of methyl groups in the molecule;

L__ average chains length.

The calculation of the structural parameters for asphaltene B is similar to the above, and the structural parameters of both asphaltenes are summarized in the Table S2.

Table S2. Structure parameters of both asphaltenes calculated from ${ }^{1} \mathrm{H}$ NMR spectra

\begin{tabular}{ccc}
\hline & \multicolumn{2}{c}{ Mean structural parameters } \\
\cline { 2 - 3 } Parameter & Asphaltene A & Asphaltene b \\
\hline $\mathrm{C}_{\mathrm{T}}$ & 57 & 51 \\
$\mathrm{H}_{\mathrm{T}}$ & 57.5 & 49 \\
$f_{\mathrm{A}}$ & 0.54 & 0.58 \\
$f_{\mathrm{N}}$ & 0.25 & 0.24 \\
$f_{\mathrm{P}}$ & 0.2 & 0.18 \\
\hline
\end{tabular}




\begin{tabular}{|c|c|c|}
\hline $\mathrm{C}_{\mathrm{A}}$ & 31 & 30 \\
\hline $\mathrm{C}_{\mathrm{N}}$ & 14 & 12 \\
\hline $\mathrm{C}_{\mathrm{P}}$ & 12 & 9 \\
\hline $\mathrm{C}_{\mathrm{S}}$ & 26 & 21 \\
\hline $\mathrm{H}_{\mathrm{AU}} / \mathrm{C}_{\mathrm{A}}$ & 0.30 & 0.38 \\
\hline$\delta$ & 0.41 & 0.31 \\
\hline $\mathrm{R}_{\mathrm{A}}$ & 9 & 8.5 \\
\hline $\mathrm{R}_{\mathrm{T}}$ & 14 & 12.5 \\
\hline $\mathrm{R}_{\mathrm{N}}$ & 5 & 4 \\
\hline $\mathrm{R}_{\mathrm{A}} / \mathrm{R}_{\mathrm{N}}$ & 1.8 & 2.125 \\
\hline $\mathrm{nCH}_{2} / \mathrm{nCH}_{3}$ & 1.24 & 1.35 \\
\hline $\mathrm{nCH}_{3}$ & 8 & 6 \\
\hline $\mathrm{L}$ & 1.4 & 1.5 \\
\hline Mean molecular formula & $\mathrm{C}_{57} \mathrm{H}_{57.5} \mathrm{~N}_{0.75} \mathrm{~S}_{1} \mathrm{O}_{4.5}$ & $\mathrm{C}_{51} \mathrm{H}_{49} \mathrm{~N}_{0.75} \mathrm{~S}_{0.75} \mathrm{O}_{7}$ \\
\hline
\end{tabular}

